\title{
Histological, Bacteriological \& Immunological Differences between the Bacilliferous Forms of Leprosy in Chinese
}

(with a note on the histological features of the paucibacillary forms)

C. S. GOODWIN, M.D., DIP. BACT.

The Leprosy Mission, London

A clearly demarcated classification of the various forms of leprosy is not only intrinsically desirable, but is essential for comparable analysis of studies of patients in different parts of the world. Classifications based solely on clinical features have led to arguments and confusion, probably because of wide pigmentary and somatic differences between various peoples; for example, borderline leprosy in the Far East has been described as being nearer to lepromatous leprosy in its clinical features than is the case in Africa (Browne, 1963). However, when the histological picture of skin lesions of untreated patients is analysed, features can be found to identify the various forms of leprosy. Ridley and Jopling $(1962,1966)$ have fully described and tested an acceptable 5-form spectrum of leprosy, in addition to the indeterminate form. Histological, clinical, bacteriological and immunological studies amongst Chinese leprosy patients have led independently to the recognition of an almost identical 5-form spectrum. These studies were initiated in 1961 . A pilot study of more than 100 skin biopsy specimens revealed that in Chinese patients a classification based on the histological features of a skin biopsy specimen correlated more closely to the subsequent clinical course than a purely clinical classification. Clearly distinguishable histological pictures were identified that corresponded to different forms of leprosy whose clinical course under treatment was markedly different from each other. The 5-form classification found in Chinese patients was included in the protocols of a study of leprosy bacilli in the nasal mucosa, and the statistically significant differences between the bacilliferous forms are reported here. Classification based on the biopsy of a skin lesion is also the method adopted at the U.S.A. Leprosarium at Carville, Louisiana (Shepard, 1960).

The importance of distinguishing evenly stained forms from irregularly stained forms of $M$. leprae in routine skin and nasal smear preparations was recognised many years ago by workers in West Africa (Davey, 1958, 1959; Browne, S. G., personal communication).

Following the suggestion of Waters and Rees (1962) that the percentage of evenly stained, morphologically normal forms of $M$. leprae should be calculated in routine Ziehl-Neelsen preparation, the term 'Morphological Index' was adopted (Goodwin, 1963), and has been accepted (Pettit and Rees, 1964, Browne, 1965).

It would appear necessary for the next International Congress of Leprology to consider a detailed classification and also the nomenclature of various forms. To enable the full range of histological features that characterise each of the forms to be appreciated, this study in Chinese leprosy patients is reported. Slight modifications or additions to the Ridley and Jopling classification may be considered. Inasmuch as the nomenclature of the intermediate forms of leprosy is still in a transitional period,

Note: Much of this study formed part of the work for a thesis for the degree of M.D. of Cambridge University. 
it may be useful to mention that in this study in Chinese patients the terms 'atypical lepromatous' and 'atypical tuberculoid' were used for the BL and BT forms of Ridley and Jopling. Although BL presumably is the sigla of Borderline Lepromatous, it is not clear that the $\mathrm{BB}$ form of Ridley and Jopling is a similar sigla of Borderline Leprosy.

\section{MATERIALS}

This report is based on a detailed study of 187 unselected Chinese leprosy patients admitted to the Hong Kong Leprosarium of the Leprosy Mission between May 1962 and May 1964 and treated there. The course of treatment was accompanied by a group of tests repeated serially. Because treatment in the Leprosarium was primarily for bacilliferous patients, very few patients at the tuberculoid end of the spectrum were studied. Three tuberculoid leprosy out-patients were studied.

The patients consisted of 136 males and 54 females, with ages ranging from 7 to 76 years.

\section{METHODS}

(a) Bacteriological. Every patient on admission to the Leprosarium was subjected to a group of tests for $M$. le prae in the skin and nasal mucosa. The whole body surface was examined for leprosy skin lesions and 6 sites were selected to ensure complete coverage of the body. These sites included one of the ear-lobes, the face, the back or chest, one arm, one leg and one buttock. At each site a leprosy lesion, if possible, was selected and the test made at the edge of the lesion. The skin lesion selected was that which was expected to have the greatest density of leprosy bacilli, and when randomly selected patients were multiply sampled, it was confirmed that skill in selecting the most bacilliferous lesion had been attained.

The nasal mucosa was sampled on both sides of the nasal septum. The mucosa was swabbed clean with dry cotton wool. The tip and edge of the nasal scraping instrument or knife were pressed firmly on to the mucosa and drawn backwards and forwards in a line of about $8 \mathrm{~mm}$. until a trace of blood exuded. The tissue was transferred to a slide and spread as a 'smear' to obtain uniform thickness. Skin and nasal smears were stained by the Ziehl-Neelsen method modified by the use of $3 \%$ hydrochloric acid in $95 \%$ alcohol for decolorisation (Davison, 1960; Padma, 1964).

The density of bacilli in skin and nasal smears was graded from 0 to 6 according to the logarithmic method of Ridley (1964). The average of the 6 skin sites was taken as the skin Bacterial Index (B.I.), and the average of the 2 nasal smears as the Nasal Bacterial Index (N.B.I.).

Patients in whom leprosy bacilli were found in the nasal mucosa were subjected to serial tests in the skin and nasal mucosa at 3-month intervals until nasal leprosy bacilli could no longer be found, or until May 1964 if nasal bacilli were still present.

(b) The Morphological Index. Using a powerful light source and a magnification of $\times 1250$, 100 to 200 individual bacilli in each skin and nasal smear preparation were examined and the percentage of evenly stained, morphologically normal leprosy bacilli in a preparation was estimated.

From the 6 skin smear sites the average percentage was calculated, and taken as the skin Morphological Index (M.I.). In the smears from the 2 slides of the nasal septum the average percentage of evenly stained, morphologically normal bacilli was taken as the Nasal Morphological Index (N.M.I.). The Morphological Index is affected more than the Bacterial Index by variable selection of sampling sites and it is desirable that a definite set of sites should be universally accepted, so that B.I. and M.I. estimations by different workers may be more comparable. The M.I. and N.M.I. were estimated in patients admitted from March, 1963.

(c) Histological. From every patient on admission a biopsy specimen was taken from the edge of an active, usually raised skin lesion. The specimen was fixed in Ridley's FormolZenker fixative (Ridley, 1957). One section was stained with haematoxylin and eosin, and one 
by the Ziehl-Neelsen method modified by the use of $10 \%$ sulphuric acid for decolorisation.

In 2 patients who exhibited markedly different skin lesions in different areas of the body, biopsy specimens from each of the 2 different lesions of each patient were found to contain basically similar histological features.

Ridley and Jopling (1966) reported that in biopsy specimens from a pair of lesions it was the exception to find any different classification features between the 2 lesions.

In Chinese patients the following features were notified for classification purposes:-

\section{Lepromatous}

The epidermis is usually thinned, and the rete pegs, or ridges, are flattened. In the subepidermal region of the dermis there is a thin zone that is free of inflammatory cells, in contrast to the rest of the dermis in which many collections or even sheets of inflammatory cells are seen. The inflammation is composed primarily of histiocytes, and macrophages with a characteristically foamy cytoplasm or 'soapbubble' appearance. These cells contain large numbers of leprosy bacilli and of ten globi. In heavy infections bacilli may be seen between the cells. In the granulatomus infiltrate plasma cells may be seen, and also varying numbers of lymphocytes. In untreated patients who have had the disease for many years, atypical giant cells, with vacuoles and a basophilic cytoplasm may be seen. Nerves in the skin exhibit perineural inflammation, but their architecture is relatively unaltered. In long-standing cases the nerves may show hyaline degeneration. Leprosy bacilli are seen in the nerves. Fig. 1 shows some clinical and histological features of a patient with lepromatous leprosy.

\section{Atypical Lepromatous}

The histological picture is basically similar to that in lepromatous leprosy, but there are the following differences:-

The sub-epidermal zone may be entirely free of inflammatory cells, or may contain a few inflammatory cells, but they are not as dense as in the rest of the dermis. The inflammation is more

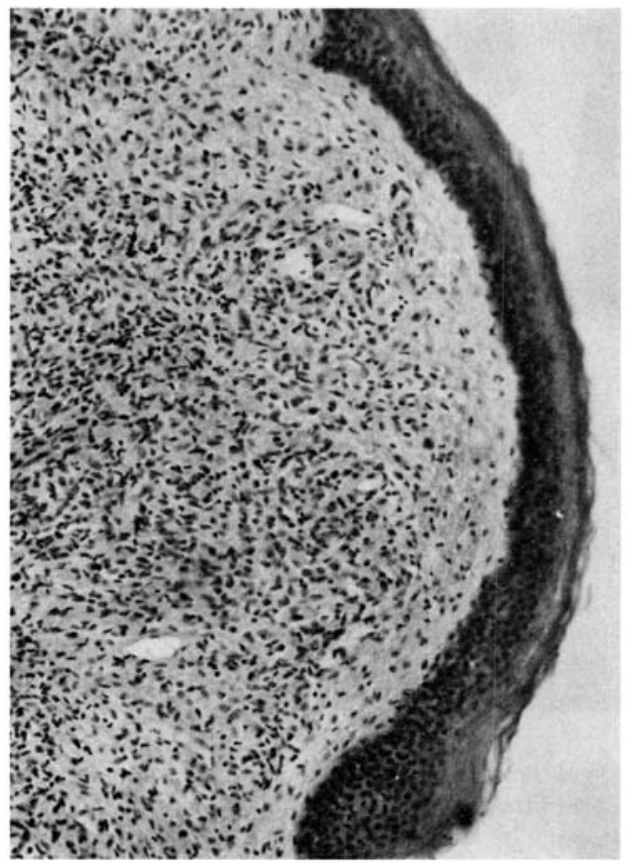

FiG. 1

Lepromatous leprosy skin lesion (Patient No. 1552). The epidermis is thinned and the rete pegs are flattened. There is a thin sub-epidermal zone which is relatively free of inflammatory cells, in contrast to the subjacent dermis in which the normal tissue is almost entirely replaced by inflammatory cells.

$\mathrm{H} \& \mathrm{E}$

$(\times 160)$

markedly focalised and there may be large numbers of lymphocytes, and fewer histiocytes may have a foamy cytoplasm. There may be a very few epithelioid cells. The nerves may show some intraneural inflammation. The number of leprosy bacilli seen may be relatively high, but there are not many globi, and there may be relatively few bacilli. Figs. 2 and 3 show clinical and histological features of patients with a typical lepromatous leprosy.

\section{Borderline}

The sub-epidermal zone usually contains a few inflammatory cells, but it is suggested that the pathognomonic features of borderline leprosy among the Chinese are that in the dermis there are both bacilli-laden, often foamy, histiocytes and also follicular groupings of epithelioid cells with one or more Langhan's type giant cells and surrounding lymphocytes. Often the inflamma- 


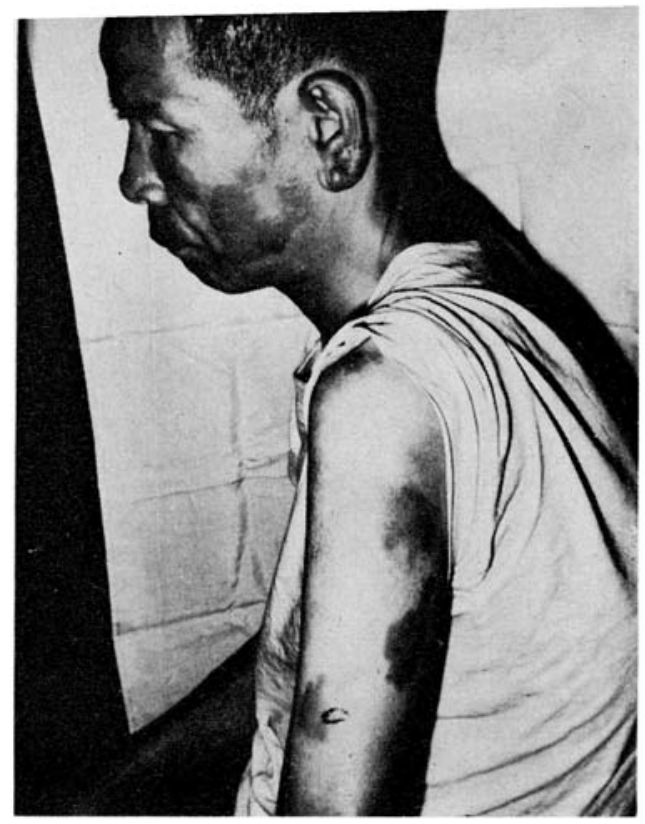

FIG. 2

Atypical lepromatous leprosy skin lesions on the left arm and face (Patient No. 1565). The lesions exhibited no sensory loss. Smear bacterial density: arm 4, face 5 . Photograph taken on admission, 12/7/63. The biopsy site is marked on the arm.

B.I. 3.8, M.I. $2 \%$, N.B.I. 0, N.M.I. $\% \%$.

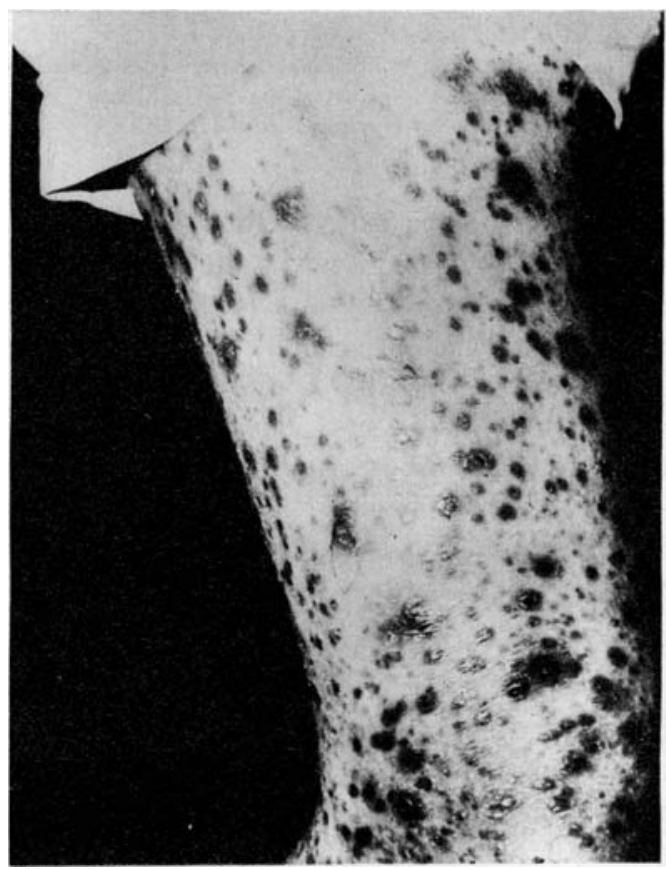

FIG. 4

The left knee and thigh of a borderline leprosy patient (No. 1544) showing multiple nodular lesions. Biopsy site marked faintly on the medial side. The lesions exhibited no sensory loss. Smear bacterial density 2 . B.I. 2.2, M.I. $1 \%$, N.B.I. 0, N.M.I. $0 \%$.

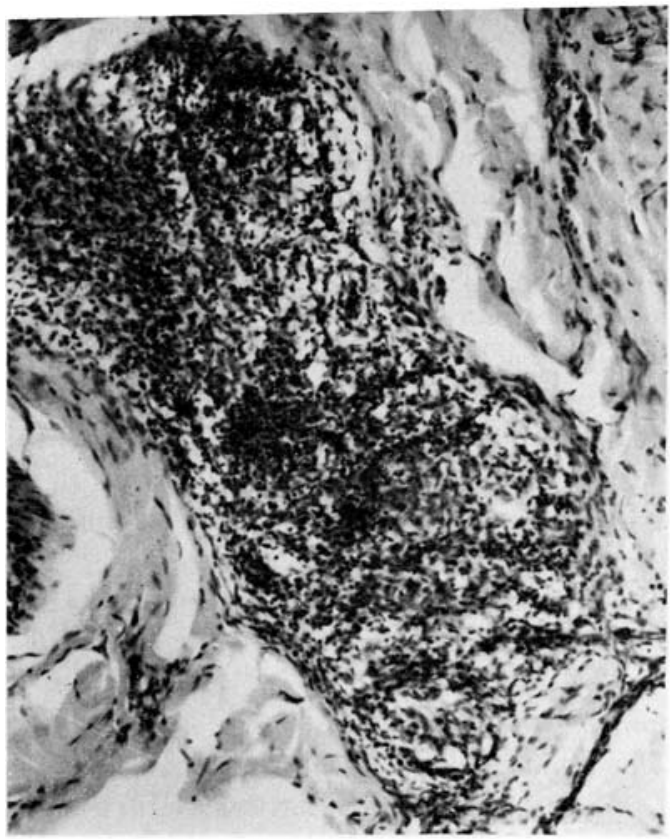

FIG. 3

The dermis of a skin lesion of an atypical lepromatous leprosy patient (No. 1565), in which is a large collection of lymphocytes and a few histiocytes.

$\mathrm{H} \& \mathrm{E}$

$(\times 120)$

(This picture is what was described for the similar form of leprosy by Ridley and Jopling (1962).)

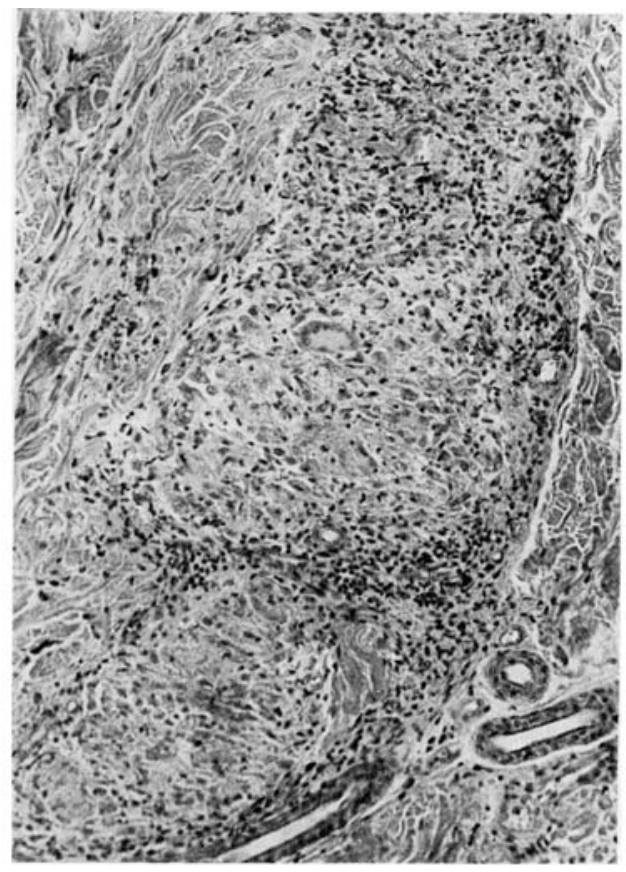

FIG. 5

The dermis of a borderline leprosy skin lesion (Patient No. 1544), in which is a large follicular grouping of epithelioid cells with a few surrounding lymphocytes, H \& E

$(\times 160)$ 


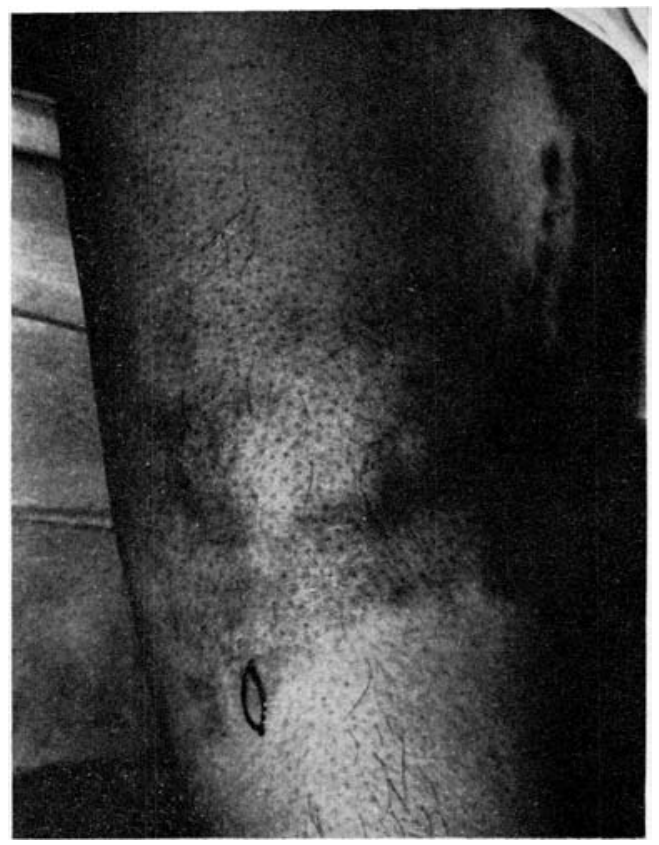

FIG. 6

Right thigh of atypical tuberculoid leprosy patient (No. 1564). The skin lesion consists of a large macule with central hypopigmentation and peripheral satellite lesions. The lesions exhibited sensory loss, to touch and pin-prick. Smear bacterial density l. Biopsy site marked. Photograph taken on admission, $12 / 7 / 63$. B.I. I, M.I. () $\%$, N.B.I. 0, N.M.I. $0 \%$

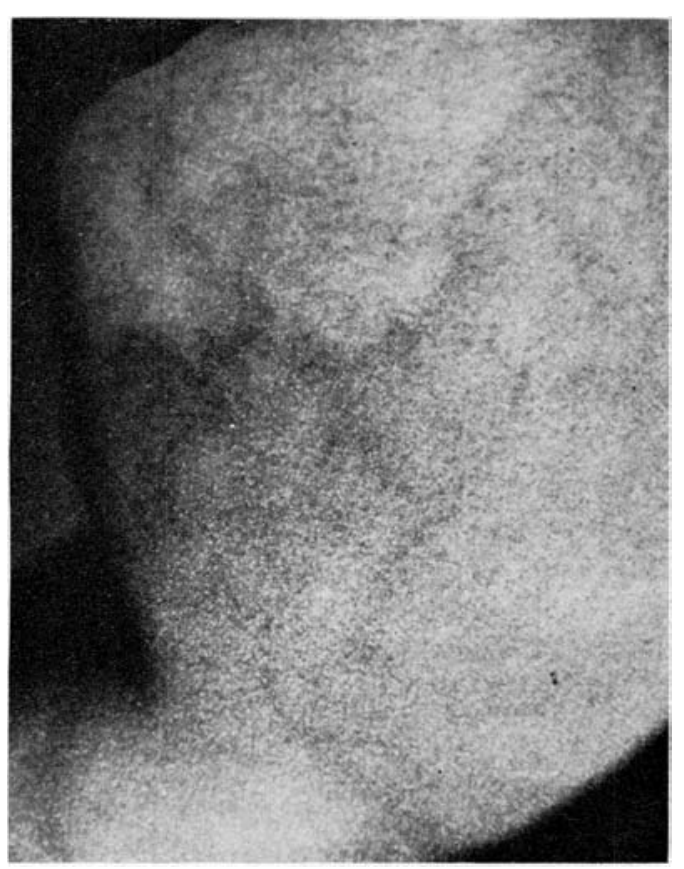

FIG. 8

Thigh of tuberculoid leprosy patient with macular lesion. The lesion was anaesthetic. Patient No. OP 787. Photograph taken 30/1/64. B.I. 0, N.B.I. 0 .

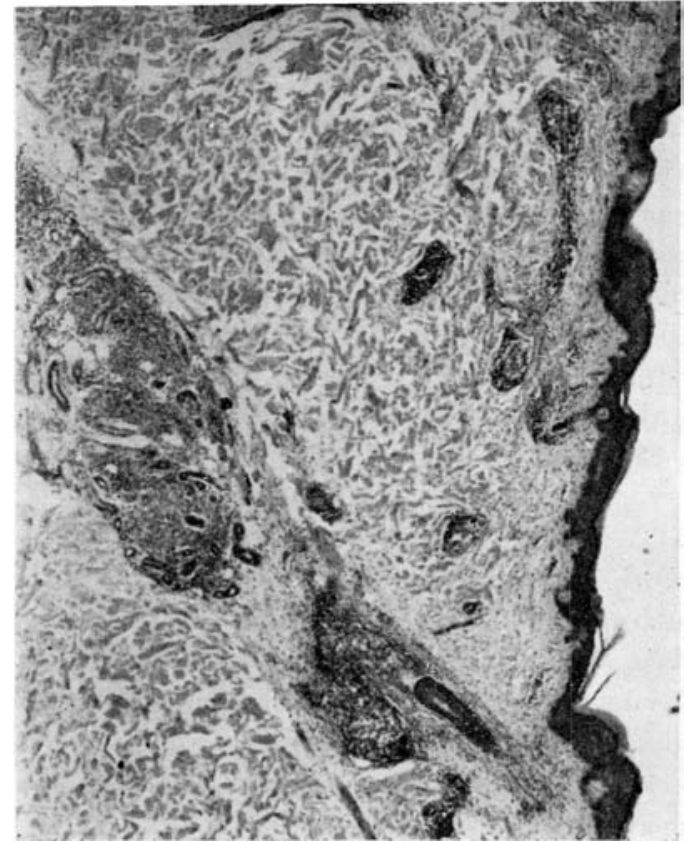

FI(. 7

Skin lesion of atypical tuberculoid leprosy patient (No. 1564). The sub-epidermal region contains less inflammatory granuloma than the underlying dermis. The dermis contains focalised epithelioid cells and some lymphocytes.

$\mathrm{H} \& \mathrm{E}$

(These features are the same as those described for the same form of leprosy by Ridley and Jopling (1962).)

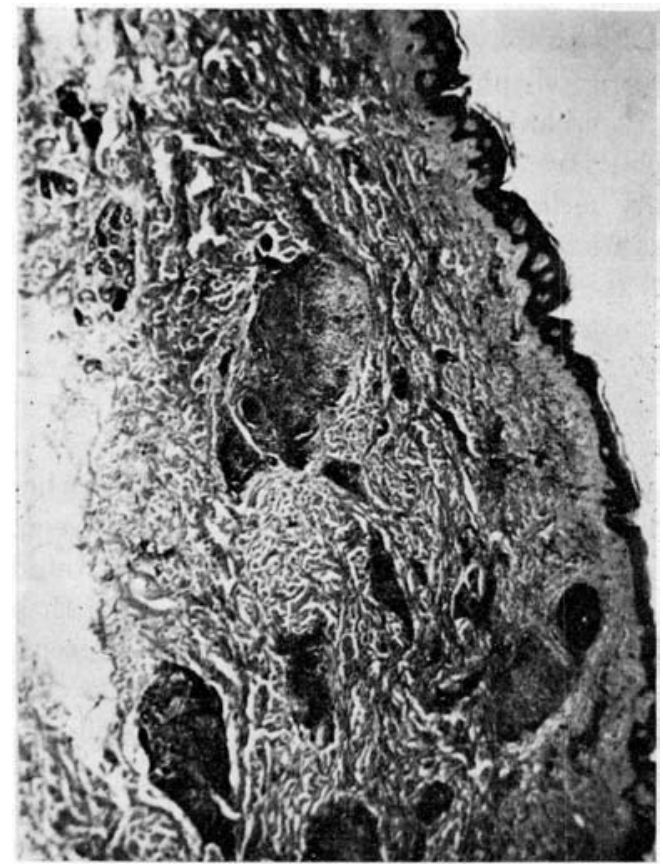

FIG. 9

Skin lesion of tuberculoid leprosy patient (No. OP 787). The dermis contains follicular groupings of epithelioid cells and lymphocytes. Stain: Haematoxylin and Eosin. Biopsy taken 30/1/64.

$(\times 20)$ 
tion is markedly follicular, especially if there is no leprosy reaction, and often there are large numbers of lymphocytes. The nerves show perineural and intra-neural inflammation. Varying numbers of leprosy bacilli are found, but often very few bacilli are seen. Figs 4 and 5 show the clinical and histological features of a patient with Borderline leprosy.

\section{Atypical Tuberculoid}

Inflammatory cells are present in the subepidermal region in many parts of the section. In the dermis are epithelioid cells which may be focalised or diffuse with Langhan's giant cells and some lymphocytes. Nerves are usually extensively infiltrated with inflammatory cells. A very few leprosy bacilli may be seen. Figrs. 6 and 7 show the clinical and histological features of a patient with atypical tuberculoid.

\section{Tuberculoid}

Inflammatory cells are found in the subepidermal zone, and they may infiltrate the basal layers of the epidermis. In the dermis there are follicular groupings of epithelioid cells, with Langhan's-type giant cells and surrounding lymphocytes. The architectures of the nerves is usually entirely disrupted by intra-neural inflammation. No leprosy bacilli are seen. Figs. 8 and 9 show the clinical and histological features of a patient with tuberculoid leprosy.

\section{Indeterminate}

Inflammation is not marked, and neither epithelioid cells nor foamy histiocytes are seen. There are scattered foci of lymphocytes round the nerves and other skin appendages, with a small number of leprosy bacilli present, especially in the nerves. Fig. 10 shows the histological features of a patient with indeterminate leprosy.

(These criteria for indeterminate leprosy are the same as those subsequently delineated by the VIIIth International Congress of Leprology, Rio de Janeiro Congress, 1963.)

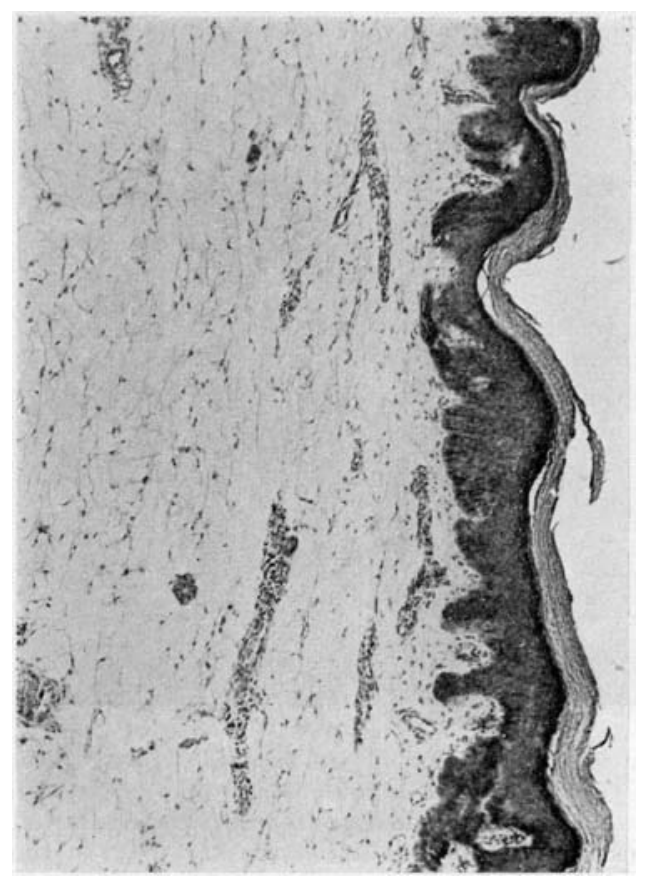

Fig. 10

Skin lesion of indeterminate leprosy patient (No. 1643). There are a very few, very small collections of chronic inflammatory cells, with intraneural A.F.B. Biopsy $\mathrm{H} \& \mathrm{E}$ taken on admission, $6 / 3 / 64$.

B.I. 3.5, M.I. $0 \%$, N.B.I. 2, N.M.I. $0 \%$.

$(\times 64)$

(d) The Lepromin Test was performed with Dharmendra-type lepromin (Dharmendra, 1941) standardised against lepromin from The Leprosy Research Unit, Uzuakoli (by kindness of Dr. S. G. Browne). The reading of the lepromin reaction was done by measuring with calipers the diameter of the infiltration which could be palpated at an interval of 21 days after the injection (Lowe and McNulty, 1953; Leiker, 1961). The reading was recorded in millimetres. A reading of $2 \mathrm{~mm}$. or more was regarded as a positive reaction. (145 patients were included in the analysis of this test.)

\section{RESULTS}

In 48 of 50 lepromatous patients $(96 \%)$, in 13 of 18 atypical lepromatous $(72.3 \%)$ and in 7 of 15 borderline patients $(46.6 \%)$ leprosy bacilli were found in smear preparations from 
TABLE 1

A comparison of the density of leprosy bacilli in the skin and nose in the different forms of leprosy

$1 \mathrm{~A}$ Lepromatous and Atypical Lepromatous Leprosy-B.I.

\begin{tabular}{cccccccc}
\hline & \multicolumn{3}{c}{ Lepromatous } \\
$\begin{array}{c}\text { Treatment } \\
(\text { months })\end{array}$ & $\begin{array}{c}\text { No. of } \\
\text { Patients }\end{array}$ & $\begin{array}{c}\text { Range } \\
\text { of B.I. }\end{array}$ & $\begin{array}{c}\text { Mean } \\
\text { B.I. }\end{array}$ & $\begin{array}{c}\text { No. of } \\
\text { Patients }\end{array}$ & $\begin{array}{c}\text { Range } \\
\text { of B.I. }\end{array}$ & $\begin{array}{c}\text { Mean } \\
\text { B.I. }\end{array}$ & $t$ \\
\hline 0 & 50 & $2.8-5.5$ & 4.30 & 18 & $0.5-4.5$ & 3.12 & 5.46 \\
3 & 76 & $2.3-6.0$ & 4.16 & 40 & $0.3-5.0$ & 3.07 & 6.813 \\
6 & 64 & $1.7-5.5$ & 3.69 & 20 & $0.3-4.5$ & 2.37 & 5.696 \\
9 & 48 & $1.7-5.3$ & 3.38 & 8 & $1.0-3.0$ & 2.20 & 3.806 \\
\hline
\end{tabular}

1 B Atypical Lepromatous and Borderline Leprosy-B.I.

\begin{tabular}{ccccccccc}
\hline & \multicolumn{3}{c}{ Atypical Lepromatous } & \multicolumn{5}{c}{ Borderline } \\
Treatment $\begin{array}{c}\text { Mean } \\
\text { (months })\end{array}$ & $\begin{array}{c}\text { No. of } \\
\text { Patients }\end{array}$ & $\begin{array}{c}\text { Range } \\
\text { of B.I. }\end{array}$ & $\begin{array}{c}\text { Mean } \\
\text { B.I. }\end{array}$ & $\begin{array}{c}\text { No. of } \\
\text { Patients }\end{array}$ & $\begin{array}{c}\text { Range } \\
\text { of B.I. }\end{array}$ & $\begin{array}{c}\text { Mean } \\
\text { B.I. }\end{array}$ & $t$ \\
\hline 3 & 40 & $0.3-4.5$ & 3.07 & 17 & $0.3-4.8$ & 1.70 & 4.419 \\
9 & 8 & $1.0-3.0$ & 2.20 & 2 & $0.3-1.0$ & 0.65 & 2.768 & $<0.001$ \\
\hline
\end{tabular}

1G The Nasal B.I. in Lepromatous and Atypical Lepromatous Leprosy

\begin{tabular}{cccccccc}
\hline & \multicolumn{3}{c}{ Lepromatous } & \multicolumn{3}{c}{ Atypical Lepromatous } \\
$\begin{array}{c}\text { Treatment } \\
(\text { months })\end{array}$ & $\begin{array}{c}\text { No. of } \\
\text { Patients }\end{array}$ & $\begin{array}{c}\text { Range } \\
\text { of N.B.I. }\end{array}$ & $\begin{array}{c}\text { Mean } \\
\text { N.B.I. }\end{array}$ & $\begin{array}{c}\text { No. of } \\
\text { Patients }\end{array}$ & $\begin{array}{c}\text { Range } \\
\text { of N.B.I. }\end{array}$ & Mean & N.B.I. \\
\hline 3 & 76 & $0-6$ & 2.53 & 40 & $0-4$ & 0.85 & 6.500 \\
6 & 64 & 0.5 & 1.88 & 20 & 0.20 & 0.60 & 4.267 \\
\hline
\end{tabular}

the nasal mucosa. The difference between the incidence in lepromatous and atypical lepromatous patients is statistically significant at the $2 \%$ level $\left(\mathrm{X}^{2}=5.63\right)$. The 2 lepromatous patients in whom nasal leprosy bacilli were not found, both had a history of the disease of less than one year.

A comparison of the density of leprosy bacilli before and during treatment in the different forms of leprosy, both in the skin and the nose (Table 1) reveals highly significant differences between lepromatous and atypical lepromatous leprosy, and between atypical lepromatous and borderline leprosy. The difference between the number of patients sampled at 0 and 3 months is due to the fact that some patients prior to admission had received a few weeks of anti-leprosy treatment. After 6 and
9 months treatment, the patients sampled were those that had a positive N.B.I. at the previous sampling.

The mean skin Morphological Index after 3 months treatment in 41 lepromatous patients was $7.06 \%$ and in 19 atypical lepromatous patients was $2.67 \%$, the difference being significant at the $5 \%$ level.

Of 29 untreated lepromatous patients, 15 had a positive N.M.I., with 9 patients having an N.M.I. between 40 and $80 \%$. However, only 2 out of 15 untreated atypical lepromatous patients had a positive N.M.I.- the highest being $10 \%$.

The lepromin reaction in all the 78 lepromatous patients was negative, but of the 38 atypical lepromatous patients, $4(10.5 \%)$ had a positive lepromin reaction. This difference is 
significant at the $2 \%$ level $\left(\mathrm{X}^{2}=5.37\right)$. Of 26 patients with borderline leprosy, $15(47.6 \%)$ had a positive reaction, the difference between this percentage and that in atypical lepromatous leprosy being significant at the $0.1 \%$ level $\left(\mathrm{X}^{2}=14.27\right)$.

\section{DISCUSSION}

A form of leprosy intermediate between borderline and tuberculoid has been suggested by Currie (1961), Leiker (1964), Cochrane (1964) and Pfaltzgraff (1967); and a form between lepromatous and borderline has been recognised by Waters and Rees (1962). The 5-form spectrum of Ridley and Jopling (1962) is supported by the present study in Chinese patients, among whom statistically significant differences both bacteriological and immunological, have been found between lepromatous, atypical lepromatous and borderline leprosy.

All the lepromatous patients were found to have a negative lepromin reaction and in all but 2 , those with a history of less than one year, nasal leprosy bacilli were found. This is similar to details in the report of Shepard (1960) of 34 patients in the U.S.A., when a positive lepromin reaction was always associated with an absence of nasal leprosy bacilli, and all the lepromatous patients in whom nasal bacilli could be found exhibited a negative lepromin reaction.

Shepard also gave details of 14 lepromatous patients in the Philippines. Two patients exhibited a positive lepromin reaction and no leprosy bacilli were found in nasal washings; but in 2 others, with a very small positive lepromin reaction of $1 \mathrm{~mm}$. diameter, some nasal leprosy bacilli were found. This observation might be explained by the fact that the 4 patients with a positive lepromin reaction were not suffering from pure lepromatous leprosy, and the findings in Chinese patients suggest that such patients might have been suffering from atypical lepromatous leprosy. The most reliable basis for recognition of the intermediate forms of leprosy would appear to be the histological picture of an active untreated skin lesion (Currie, 1961; Ridley and Jopling, 1962). The clinical features of the intermediate forms are also delineated by Ridley and Jopling (1966). They report the different rates of fall of the Biopsy Index in the different forms of leprosy, and in Chinese leprosy patients the rate of fall of the Bacterial Index has been found to be markedly different in lepromatous, atypical lepromatous and borderline leprosy. These facts illustrate the prognostic value of the 5 -form classification.

\section{SUMMARY}

Statistically significant differences, both bacteriological and immunological, between 3 bacilliferous forms of leprosy in Chinese patients are reported, the form intermediate between lepromatous and borderline leprosy being termed atypical lepromatous leprosy. This classification is based primarily on the histological features of an active untreated skin lesion. The relevant features are delineated both for the bacilliferous forms and also for tuberculoid leprosy and the form intermediate between borderline and tuberculoid which is termed atypical tuberculoid leprosy. This independent discovery of a 5 -form spectrum, almost identical to that of Ridley and Jopling $(1962,1966)$ supports the need for recognition of such a Classification.

\section{ACKNOWLEDGEMENTS}

For help with the statistical analysis, the author is indebted to Miss L. M. Colwell of the London School of Hygiene and Tropical Medicine. The author acknowledges the assistance of 2 Chinese laboratory technicians in the bacteriological and immunological observations; and the advice and encouragement of Dr. D. S. Ridley. To Dr. S. G. Browne the author is indebted for instruction in examining the morphology of $M$. leprae. The microphotographs were kindly taken by Mr. E. A. Wheeler, s.R.M.L.T., of the Histology Department of St. John's Hospital for Diseases of the Skin, London. The author thanks Mrs. Daish and her assistants for secretarial assistance.

\section{Leprosy Review}




\section{BIBLIOGRAPHY}

1. BRowne, S. G. (1963). The variegated pattern of leprosy. Lepr. in India, 26, 193-199.

2. BROWNE, s. G. (1965). A limited clinical trial of injectable Thiambutosine. Lep. Rev., 36, 21-22.

3. Cochrane, R. G. (1964). Classification. In Leprosy in theory and practice, 2nd Ed., edited by COChrane, R. G. and DAVEY, T. F., Bristol: John Wright, 299-309.

4. CURRIE, G. (1961). Macular leprosy in Central Africa with special reference to the 'maculoid' (dimorphous) form). Int. J. Lepr., 29, 473-487.

5. DAVey, T. F. (1958). Progress with new antileprosy drugs. Int. J. Lepr., 26, 299-304.

6. DAVEY, T. F. (1959). Diethyl dithiolisophthalate (ETIP or Etisul) in the treatment of leprosy; a second progress report. Lep. Rev., 30, 141-152.

7. DAvison, A. R. (1960). The technique of staining leprosy bacilli in smears. Lep. Rev., 31, 305-307.

8. DhARMENDra (1941). Studies of the lepromin test. 3. Preparation and standardisation of lepromin. Lepr. in India, 13, 77-80.

9. Goodwin, c. s. (1963). Essentials of leprosy for the clinician, lst Ed., 4. Hong Kong: Hong Kong Auxiliary of The Mission to Lepers.

10. LEIKER, D. L. (1961). Studies on the lepromin test. II. Time of reading and ulceration of the Lepromin reaction. Int. .J. Lepr., 29, 168-171.

11. LEIKER, D. L. (1964). Low-resistant tuberculoid leprosy. Int. .J. Lepr., 32, 359-367.

12. LEIKER, D. L. (1966). Classification of Leprosy. Lep. Rev., 37, 7-15.

13. LOWE, J. and mCNulty, F. (1953). Tuberculosis and leprosy. Immunological studies. Lep. Rev., 24, 61-89.
14. PAdmA, M. N. (1964). A standard technique of acid-fast staining for $M$. leprae in smears. Lepr. in India, 35, 62-64.

15. Pettit, J. H. S. and Rees, R. J. W. (1964). Sulphone resistance in leprosy. Lancet, 2, 673-674.

16. Pfaltzgraff, R. E. (1967). The classification of leprosy. Lep. Rev., 38, 15-23.

17. RIDlEy, D. S. (1957). The use of biopsies in therapeutic trials in leprosy. Trans. R. Soc. Trop. Med. \& Hyg., 51, 152-156.

18. RIDLEY, D. S. (1964). Bacterial indices. In Leprosy in theory and practice, 2nd Ed., edited by COCHRANE, R. G. and DAVEY, T. F. Bristol: John Wright, 620

19. RIDLEY, D. S. and Jopling, w. H. (1962). A classification of leprosy for research purposes. Lep. Rev., 33, $119-128$.

20. RIDLEY, D. S. and JOPLING, W. H. (1966). Classification of leprosy according to immunity. A five-group system. Int. .J. Lepr., 34, 255-273.

21. RIO DE JANEIRO CONGRESS (1963). VIIIth International Congress of Leprology. Report of the Round Table on Borderline and Indeterminate Leprosy. Int. .J. Lepr., 31, 480.

22. ShEPARD, C. C. (1960). Acid-fast bacilli in nasal excretions in leprosy, and results of inoculation of mice. Amer. J. Hyg., 71, 147-157.

23. WATERS, M. F. R. and ReEs, R. J. W. (1962). Changes in the morphology of Mycobacterium leprae in patients under treatment. Int. .J. Lepr., 30, $266-277$. 